\title{
Review \\ Combination of Modern Radiotherapy and New Targeted Treatments for Breast Cancer Management
}

\author{
Arnaud Beddok ${ }^{1,2,3, *}$, Paul Cottu ${ }^{4}$ (D) Alain Fourquet ${ }^{1}$ and Youlia Kirova $^{1}$ (D) \\ 1 Department of Radiation Oncology, Institut Curie, 75005 Paris, France; alain.fourquet@curie.fr (A.F.); \\ youlia.kirova@curie.fr (Y.K.) \\ 2 Department of Radiation Oncology, Institut Curie, 91400 Orsay, France \\ 3 Laboratory of Translational Imaging in Oncology (LITO), UMR (U1288), Institut Curie, 91400 Orsay, France \\ 4 Department of Medical Oncology, Institut Curie, 75005 Paris, France; paul.cottu@curie.fr \\ * Correspondence: arnaud.beddok@curie.fr or a.beddok@gmail.com; Tel.: +33-144324504
}

Citation: Beddok, A.; Cottu, P.; Fourquet, A.; Kirova, Y. Combination of Modern Radiotherapy and New Targeted Treatments for Breast Cancer Management. Cancers 2021, 13, 6358. https://doi.org/10.3390/

cancers 13246358

Academic Editor: David N. Danforth

Received: 26 November 2021

Accepted: 14 December 2021

Published: 18 December 2021

Publisher's Note: MDPI stays neutral with regard to jurisdictional claims in published maps and institutional affiliations.

Copyright: (c) 2021 by the authors Licensee MDPI, Basel, Switzerland. This article is an open access article distributed under the terms and conditions of the Creative Commons Attribution (CC BY) license (https:// creativecommons.org/licenses/by/ $4.0 /)$.
Simple Summary: Since the introduction of hormone therapy for the treatment of breast cancer (BC) three decades ago, many new targeted therapies have been developed. Some of them are currently used, such as HER2 inhibitors, while others are still under development, such as cell cycle (CDK) inhibitors, immune checkpoint (PD1/PDL1) inhibitors, or molecules acting on DNA damage (PARP) repair. Besides this, radiation therapy (RT) is commonly used either as adjuvant treatment for early $\mathrm{BC}$ after breast conservative surgery or in palliative intent for the treatment of metastatic sites. Our research has shown that the combinations of the most commonly used targeted treatments and RT were feasible with a few toxicities. Nevertheless, most of the knowledge on this subject is based on retrospective studies and a small number of patients and care should be taken in this setting until these results would be confirmed in prospective randomized studies.

Abstract: Background: The objective of the present study was to review the essential knowledge about the combinations of the most commonly used or under development targeted treatments and radiation therapy (RT). Methods: Preclinical and clinical studies investigating this combination were extensively reviewed. Results: Several studies showed that the combination of RT and tamoxifen increased the risk of radiation-induced pulmonary toxicity; therefore, both modalities should not be given concomitantly. The combination of HER2 inhibitors (trastuzumab, pertuzumab) and RT seems to be safe. However, trastuzumab emtansine (T-DM1) should not be administered concurrently with brain RT since this combination could increase the risk of brain radionecrosis. The combination of RT and other new target treatments such as selective estrogen receptor degradants, lapatinib, cell cycle inhibitors, immune checkpoint inhibitors, or molecules acting on DNA damage repair seems feasible but was essentially evaluated on retrospective or prospective studies with a small number of patients. Furthermore, there is considerable heterogeneity among these studies regarding the dose and fractionation of radiation, the dosage of drugs, and the sequence of treatments used. Conclusions: The combination of RT with most targeted therapies for BC appears to be well-tolerated, but these results need to be confirmed in prospective randomized studies.

Keywords: multimodal treatment; radiation tolerance; drug tolerance

\section{Introduction}

Radiation therapy (RT) is one of the most common therapeutic modalities, along with surgery and systemic treatment, for the treatment of breast cancer (BC). Many studies have demonstrated the interest of RT as adjuvant treatment for early BC after breast conservative surgery [1]. RT is also currently used in palliative intent for the treatment of metastatic sites. In both contexts, RT is potentially combined with several different drugs. In this situation, the question is often asked whether these two treatments can be combined concomitantly or whether the systemic treatment should be suspended during RT. The objective of the 
present study was to review the essential knowledge about the combinations of the most commonly used targeted treatments and RT (Figure 1). For each molecule, we emphasize the safety and the new developments of this combination.

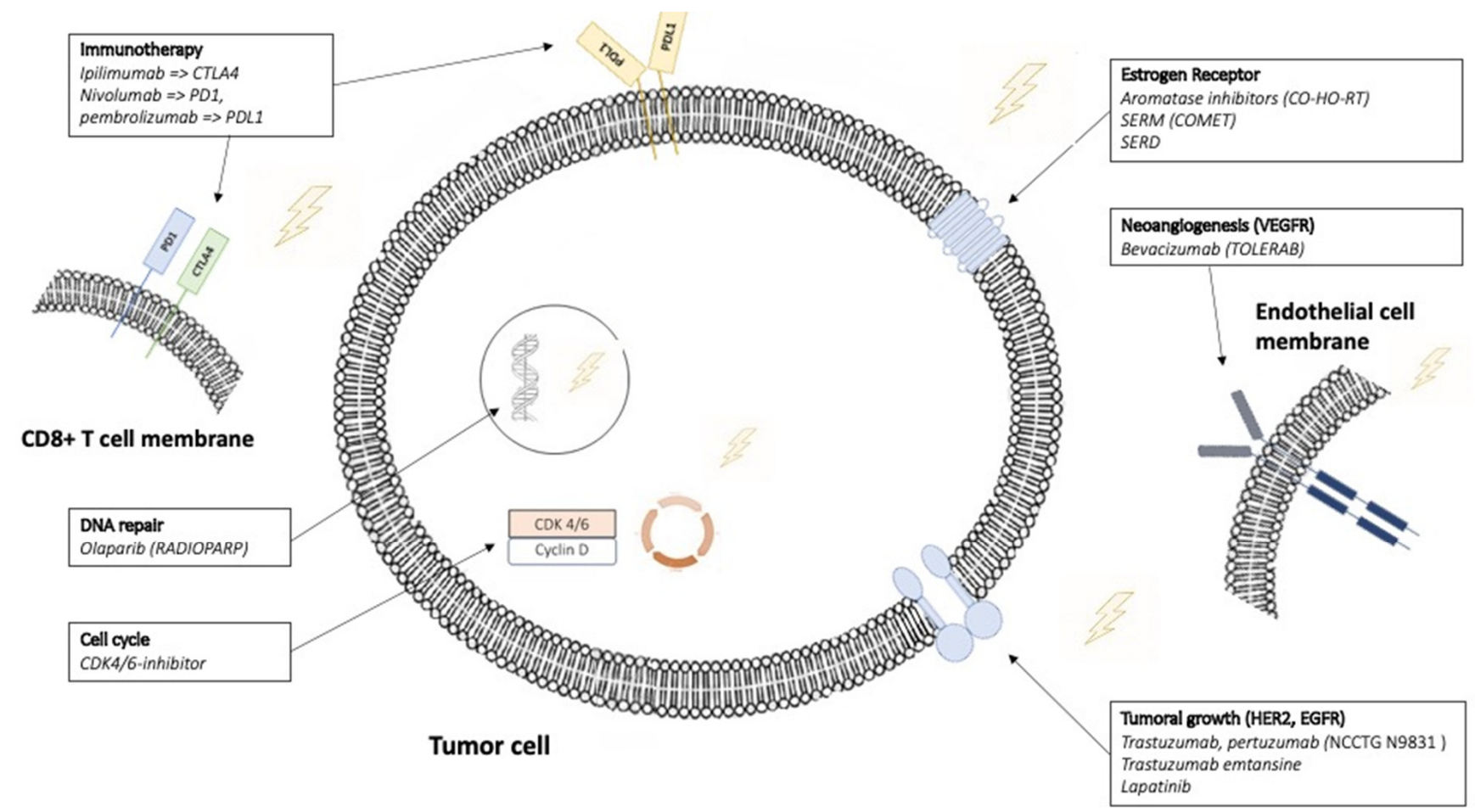

Figure 1. Targeted treatments evaluated in combination with radiotherapy. This figure illustrates the six target types of treatments for which combination with radiation therapy was described in this review. HER2: Human Epidermal growth factor Receptor 2, EGFR: Epidermal growth factor Receptor.

\section{Materials and Methods}

References for this review were identified through searches of PubMed with the search terms "tamoxifen AND radiotherapy", "aromatase inhibitor and radiotherapy", "SERD and radiotherapy", "Human Epidermal growth factor Receptor 2-inhibitor and radiotherapy", "Vascular endothelial growth factor inhibitor and radiotherapy", "immunotherapy and radiotherapy", "CDK inhibitor and radiotherapy", and "Olaparib and radiotherapy" from 1990 until June 2021. Articles were also identified through searches of the authors' own files. Only papers published in English were reviewed. The final reference list was generated on the basis of originality and relevance to the broad scope of this Review. We also conducted research on the https:/ / clinicaltrials.gov/ct2/home (accessed on 13 December 2021) website to assess the ongoing randomized trials about the combination of RT and targeted treatments in BC (Table 1). 
Table 1. Main ongoing randomized clinical trials testing the combination of targeted treatments and RT for breast cancer treatment (accessed on date 2021 December)

\begin{tabular}{|c|c|c|c|c|}
\hline Target & Name & Number & Recruitment Status & Endpoint \\
\hline $\begin{array}{c}\text { Estrogen receptor (ER) } \\
\text { Tamoxifen + locoregional RT }\end{array}$ & CONSET trial & NCT00896155 & Unknown & Pulmonary fibrosis \\
\hline $\begin{array}{c}\text { Tumor growth } \\
\text { Trastuzumab Emtansine (T-DM1) + brain RT }\end{array}$ & BIRTH trial & NCT02135159 & Completed & Brain radionecrosis \\
\hline $\begin{array}{c}\text { Tumor angiogenesis } \\
\text { Bevacizumab + brain RT }\end{array}$ & A-Plus & NCT02185352 & $\begin{array}{l}\text { Active, not } \\
\text { recruiting }\end{array}$ & $\begin{array}{l}\text { Brain-specific } \\
\text { progression free } \\
\text { survival }\end{array}$ \\
\hline $\begin{array}{c}\text { Cell cycle } \\
\text { Palbociclib + locoregional RT }\end{array}$ & PALATINE & NCT03870919 & Recruiting & Overall survival \\
\hline $\begin{array}{c}\text { DNA repair } \\
\text { Olaparib }+/- \text { locoregional RT }\end{array}$ & & NCT03598257 & Recruiting & $\begin{array}{c}\text { Invasive Disease-Free } \\
\text { Survival }\end{array}$ \\
\hline
\end{tabular}

\section{Results}

\subsection{Hormonotherapy}

The inhibition of the estrogen receptor (ER) pathway is currently one of the main treatment strategies for ER-positive breast cancer (BC). The three main methods available to target the estrogenic pathway are: aromatase and $\mathrm{GnRH}$ (gonadotropin hormone analogues) inhibitors, which induce a decrease in the endogenous production of estradiol; the selective estrogen receptor modulators (SERMs), which bind directly to estrogen; and the selective estrogen receptor degradants (SERDs), which induce estrogen receptor degradation [2].

Several pre-clinical and retrospective clinical studies have suggested that the concomitant and/or sequential combination of tamoxifen and breast irradiation could induce a risk of pulmonary fibrosis (PF) [3]. The key mechanism explaining the increase PF when combining tamoxifen and RT would be via the induction of TGF- $\beta$ synthesis. In 1992, Butta et al. [4] studied the effect of tamoxifen on the regulation of TGF $\beta$ in vivo. Three months after tamoxifen treatment, a dramatic increase in the extracellular TGF- $\beta 1$ was detected in repeated biopsies in all 10 studied patients. In 2013, Yavas et al. [5] confirmed this result when they compared in vivo the effect of aromatase inhibitors (anastrozole and letrozole) and tamoxifen on radiation-induced PF. Eighty female Wistar albino rats were divided into several groups to compare RT alone, the combination of RT and tamoxifen, and the combination of RT and aromatase inhibitor. A single dose of 12 Gy RT was given to both lungs. Tamoxifen, anastrozole, and letrozole were started 1 week before the RT and continued until the animals were sacrificed 16 weeks after the RT. When compared with the RT only group, the concomitant RT and tamoxifen group increased the radiation-induced pulmonary fibrosis $(p=0.005)$. In a prospective randomized study, Bentzen et al. (1996) [6] examined the effect of tamoxifen on the incidence of PF in patients treated with mastectomy and adjuvant RT with or without concomitant tamoxifen. They found a statistically significant two-fold increase in PF if the patients had been receiving tamoxifen. Several other prospective studies have shown that tamoxifen was an independent risk factor of PF when combined with RT $[7,8]$. However, two other retrospective clinical studies did not identify any differences between the concomitant or sequential use of tamoxifen for the risk of $\mathrm{PF}[9,10]$. A randomized trial is currently ongoing to compare the risk of radiation-induced lung toxicity among patients receiving tamoxifen concurrently or sequentially with RT (NCT00896155, accessed on date 2021 December) [11]. For now, there is more evidence to suggest that the combination of RT and tamoxifen increases the risk of radiation-induced pulmonary toxicity and that they should not be given concomitantly. 
Moreover, there is clinical evidence that five years of adjuvant aromatase inhibitor (AI) improves recurrence-free survival in postmenopausal early BC patients. Indeed, results from the ATAC trial [12] demonstrated that recurrence rates remained significantly lower on anastrozole compared with tamoxifen. In 2007, Bollet et al. [13] have reported that AI and RT could be given concurrently to post-menopausal patients with both acceptable safety and good efficacy. The safety of AI and concurrent adjuvant radiotherapy was also shown in the CO-HO-RT trial, a prospective randomized phase 2 study [14]. The authors found no increase in cutaneous toxicity in $\mathrm{BC}$ patients receiving letrozole and concurrent normofractionated breast RT, delivering 2 Gy per daily fraction. Concurrent AI did not decrease the efficacy of irradiation at a median follow-up of 26 months. Moreover, Chargari et al. [15] (2012) evaluated the toxicity of concurrent use of AI and hypofractionated RT in 19 patients. At the end of the RT course, acute toxicity was low in most patients, with only 1 grade 3 cutaneous toxicity. Besides this, AI did not increase the risk of radiation-induced toxicity [5]. Although this is not common practice in France, these results suggest that aromatase inhibitors could be started during RT. This was done and recommended during the COVID-19 period to avoid delaying the start of treatment for patients [16].

Among the SERD, fulvestrant is unique amongst currently approved ER ligand therapeutics due to its classification as a full ER antagonist [17]. However, the full clinical potential of fulvestrant is thought to be limited by its poor physicochemical properties and exposure limitations due to its administration by intramuscular injection. Metcalfe et al. (Abstract P5-04-07 SABCS 2019) recently described for the first time GDC-9545 which, like fulvestrant, consistently induced ER turnover and drove deep transcriptional suppression of ER, resulting in a robust in vitro anti-proliferative activity [18]. The in vivo efficacy of GDC-9545 in this model was greater than fulvestrant at clinically relevant exposures. Currently, two phase I-II clinical trials are evaluating the outcomes and toxicities of this new drug in locally advanced or metastatic ER + BC patients. NCT03916744 (accessed on date 2021 December) is evaluating the pharmacodynamics, pharmacokinetics, safety, and biologic activity of GDC-9545 in participants with Stage I-III operable ER +, HER2 -, untreated BC. NCT03332797 (accessed on date 2021 December) is evaluating the safety, pharmacokinetic (PK), pharmacodynamic (PD) activity, and preliminary anti-tumor activity of GDC-9545 as a single agent and in combination with palbociclib and/or luteinizing hormone-releasing hormone (LHRH) agonist in participants with advanced or metastatic ER +, HER2 -, BC. Several other oral SERD (such as Elacestrant (RAD1901) [19,20], AZD9496, and LSZ102) are in clinical development [21]. The combination of RT and these molecules has not yet been evaluated.

\subsection{Target the Tumor Growth: HER-2 Inhibitor}

Currently, four molecules targeting the Human Epidermal growth factor Receptor 2 (HER2 receptor) are commonly used in the management of patients with $\mathrm{BC}$, mainly at the metastatic stage: trastuzumab, pertuzumab, lapatinib, and T-DM1.

Trastuzumab and pertuzumab are both humanized monoclonal antibodies, directed against the extracellular domain of the receptor. This induces blocking the MAP kinase signaling pathways and the PI3K-Akt pathway, which slows the cell cycle and decreases tumor cell proliferation [22]. Double blockage consists of the concurrent administration of Trastuzumab and Pertuzumab. Several preclinical studies using BC models have shown that anti-HER2 therapy could act as a radiosensitizer $[23,24]$. In particular, Hou et al. recently conducted in vitro and in vivo studies to investigate whether HER-2 overexpression was associated with radiosensitivity in BC [24]. They found that HER-2 reduced radiosensitivity in two BC cell lines, MCF-7 (low HER2 expression) and MDA-MB-231 (HER2 is not expressed). Moreover, animal experiment results showed HER2 could enhance the radioresistance of xenograft tumors. For early BC management, sequential anthracycline and taxanes administered concurrently with trastuzumab or docetaxel, carboplatin, and trastuzumab for six cycles are recommended in high-risk HER2-positive disease. An alternative regimen in a lower-risk, node-negative, HER2-positive population is paclitaxel and 
trastuzumab [25]. Considering these indications, trastuzumab is frequently administered concomitantly with locoregional radiotherapy. The main issue in the combination of an HER inhibitor and locoregional breast RT would be the risk of cumulative cardiac toxicity. Indeed, it is known that independently, HER2 blockade on the one hand [26] and locoregional RT for BC [27], especially in case of breast node irradiation, on the other hand, could induce cardiac toxicity. Several retrospective and prospective studies have evaluated the skin and cardiac toxicity of this combination (Table 1 [28-32]). The ranges of $\geq$ Grade 2 cardiac, skin, and esophagitis toxicity were $0-25.8 \%, 2.9-30.9 \%$, and $1.6-12 \%$, respectively. In 2009, Halyard et al. carried out an ancillary study of the NCCTG Phase III Trial N9831 study in which they investigated the acute and late safety of this combination in 982 patients treated for BC (adjuvant treatment) [30]. No significant differences among arms were found in the incidence of acute skin reaction, pneumonitis, dyspnea, cough, dysphagia, or neutropenia. At a median follow-up of 3.7 years, RT with trastuzumab did not increase the relative frequency of cardiac events regardless of the treatment side. Several more recent retrospective studies reported the good safety of the combination of RT and dual HER2 receptor inhibitor $[33,34]$. In particular, Aboudaram et al. have recently shown that the administration of dual HER2 blockade in 55 patients receiving locoregional RT was safe in terms of skin, gastrointestinal, and general toxicity [31]. No significant cardiac toxicity was observed, apart from a slight decrease in left ventricular ejection fraction (LVEF), which is expected during the HER2 blockade [26]. Besides this, as these treatments are used in patients with metastatic BC, it is also important to know the tolerance of the combination HER2 inhibitor and RT for brain metastases (BM) [35]. Chargari et al. (2011) have shown in 31 patients low toxicity of trastuzumab concurrently with whole-brain radiation therapy (WBRT) [36]. To our knowledge, no study has yet tested the combination of trastuzumab and stereotactic radiotherapy (SBRT). Based on these results, it appears that trastuzumab and pertuzumab could be administered concurrently with radiotherapy, either regionally or at metastatic sites (such as the brain). To our knowledge, no prospective or randomized clinical randomized trials are currently ongoing on this subject.

Trastuzumab emtansine (T-DM1) is an antibody-drug conjugate currently approved as monotherapy for the second-line treatment for HER2-positive metastatic BC pretreated by trastuzumab and taxanes [37]. Two recent studies reported that the combination of SBRT and TDM1 in patients with BM was possible but with an increased risk of brain radionecrosis [38,39]. Two randomized trials (NCT02135159, NCT03190967, accessed on date 2021 December) are currently ongoing on this subject and probably will allow one to specify the best appropriate time between treatments. Given these results, TDM1 should not be administered concurrently with brain radiotherapy, before the results of both clinical trials. Moreover, since the KATHERINE trial results [40], patients with HER2-positive BC with pathologic invasive residual disease at surgery after standard preoperative chemotherapy and HER2-targeted therapy should be offered 14 cycles of adjuvant TDM1 [41]. In a recent study, Mignot et al. [42] have evaluated the in vitro effects of T-DM1 and concurrent irradiation on HER2-positive BC cells. Their results indicated that T-DM1 was not a radiation-sensitizer, assessing cell survival. To our knowledge, no in vivo study was currently published on this subject. Zolcsák et al. have also recently reported in a retrospective study of 14 patients that TDM- 1 concomitantly administered with locoregional RT was well supported, without high-grade cardiac toxicity [43]. Of course, these results were obtained using a small number of subjects, and a validation cohort would be necessary to confirm these results. In the meantime, it would be preferable not to combine locoregional radiotherapy and TDM1 concurrently.

Lapatinib is a reversible dual tyrosine kinase inhibitor (TKI) targeting the epidermal growth factor (EGFR, ErbB-1) and HER2 (ErbB-2). Several preclinical studies using BC models have shown that lapatinib could be a radiosensitizer. Yu et al. (1996) conducted an in vitro experiment using SKBR3 and BT474 breast carcinoma cells exhibiting HER2/neu amplification. Pretreatment of lapatinib increased the radiosensitivity of both BC cells lines. Moreover, Sambade et al. (2010) demonstrated that lapatinib could radiosensitize 
HER2+ SUM225 BC xenografts [44]. Lapatinib has demonstrated effectiveness in BM from HER2-overexpressing BC. WBRT in association with lapatinib was well tolerated in a cohort of 21 patients with BM from BC [45]. In a retrospective cohort study, lapatinib in combination with SBRT significantly increased intracranial complete response rate $(35 \%$ versus $11 \%$ ) [46]. Concurrent lapatinib was not associated with an increased risk of grade $2+$ radiation necrosis $(1.0 \%$ with concurrent lapatinib vs. $3.5 \%$ without, $p=0.27)$. Several prospective phase 2 cohorts (NCT00470847, NCT01622868, NCT00379509, accessed on date 2021 December) are ongoing to evaluate the tolerance and the outcomes of a combination of lapatinib and WBRT. To our knowledge, there are currently no published results about the combination of locoregional RT and lapatinib. A prospective phase 2 cohort (NCT01868503, accessed on date 2021 December) is ongoing to evaluate the tolerance and the outcomes of a combination of lapatinib and locoregional RT. Several other clinical studies such as NCT04582968 or NCT01494662 (accessed on date 2021 December), are ongoing and will allow assessing the safety and the efficacy of RT combined with respectively pyrotinib and neratinib, for patients with BM from BC. The published results were obtained using a small number of subjects. In the attempt of the results of mentioned clinical trials, it would be preferable not to combine RT and lapatinib concurrently.

\subsection{Target the Tumor Angiogenesis: VEGF-Inhibitor}

Bevacizumab is a VEGF-targeting monoclonal antibody. Several clinical trials demonstrated the interest of bevacizumab for improving progression-free survival and response in patients with advanced or metastatic BC $[47,48]$. From these studies, only limited data were available concerning the safety of the combination of bevacizumab and locoregional or palliative radiotherapy. However, several preclinical studies with different models have shown that VEGF inhibitor could have a radiosensitizing effect when it is combined with radiotherapy (RT) $[49,50]$. As for the other molecules presented in this review, a radiosensitizing effect could be useful for the anti-tumor efficacy of radiotherapy but could be responsible for an increase in radiation-induced toxicities. In 2011, Goyal et al. [51] reported the outcomes and toxicity of the first fourteen patients treated with the combination of bevacizumab and locoregional RT for BC. None of the patients receiving bevacizumab plus RT experienced $\geq$ Grade 3 toxicity within the irradiated volume. Moreover, from October 2007 to August 2010, the French multicenter non-interventional observational cohort TOLERAB study included patients with non-metastatic BC treated by local or locoregional radiotherapy and concurrent bevacizumab after either neoadjuvant or adjuvant chemotherapy in the trials BEVERLY 1, BEVERLY 2, BEATRICE, or BETH [52]. Acute and early late toxicities were acceptable: Grade 3 acute radiation dermatitis was observed for only four patients, none patients had grade 3 pneumonitis or esophagitis. Clement Zhao et al. [53] recently reported the 5-years outcomes of 46 patients included in this prospective study. Only eight patients reported late toxicity, none grade 3 . For the few patients currently being treated with bevacizumab for localized BC, bevacizumab may be administered concomitantly with RT. The A-Plus trial (NCT02185352, accessed on date 2021 December) is currently ongoing to assess to outcomes and toxicity of the combination of bevacizumab and WBRT.

\subsection{Immunotherapy}

Among the many different types of immunotherapies currently being studied, immune checkpoint inhibitors (ICI) are the most employed. Ipilimumab is an anti-CTLA-4 antibody and Nivolumab and pembrolizumab act on the PD-1/PD-L1. These treatments are designed to restore the capacity of the immune system to recognize and eliminate a tumor. Several preclinical studies have investigated the combination of an ICI and RT. In 2005, Demaria et al. [54] have in particular showed that when a poorly immunogenic murine model of metastatic BC (4T1 cells) was implanted subcutaneously in mice, the combination of 9H10 (an anti- CTLA-4 antibody) and RT was the only regimen which allowed an improvement of survival and especially CTL-mediated inhibition of the formation of 
lung metastases. Verbrugge et al. [55] also showed that the antitumor effects of RT, in established triple-negative breast tumors could be enhanced in particular with anti (PD)-1 antibody. One explanation for these results could be the upregulation of PD-L1 in the tumor microenvironment after RT [56]. In a recent study, Ho et al. (2019) have for the first time prospectively studied pembrolizumab in combination with RT in patients with triple-negative BC with at least two evaluable lesions [57]. The response rates of nonirradiated lesions in the three patients with partial response were $60 \%, 54 \%$, and $34 \%$, and these responses were lasting (31, 21, and 40 weeks). In 2020, Barroso-Sousa et al. [58] performed a prospective study to investigate whether combining pembrolizumab with palliative RT improves outcomes in patients with hormone receptor-positive metastatic BC. Unfortunately, there were no objective responses, and the study was closed before the scheduled end of recruitment. Several prospective studies on the combination of ICI and RT for BC treatment are currently ongoing (see Table 2 of [59]). It should be noted that only a few data are currently available concerning the toxicity of combined ICI and RT [60], and for the moment, the combination of both treatments should be reserved for clinical trials.

Table 2. Main studies investigated the combination of HER2 inhibitor and locoregional breast cancer radiation therapy.

\begin{tabular}{|c|c|c|c|c|c|c|c|c|}
\hline Studies & $\begin{array}{l}\text { Prospective/ } \\
\text { Retrospective }\end{array}$ & $\begin{array}{c}\text { Number } \\
\text { of } \\
\text { Patients }\end{array}$ & $\begin{array}{c}\text { Mono or } \\
\text { Double } \\
\text { HER2 } \\
\text { Blockage }\end{array}$ & $\begin{array}{l}\text { IMC } \\
\text { Irradi- } \\
\text { ation }\end{array}$ & Anthracyclines & $\begin{array}{l}\geq \text { Grade } 2 \\
\text { Cardiac } \\
\text { Toxicity }\end{array}$ & $\begin{array}{l}\geq \text { Grade } \\
2 \text { Skin } \\
\text { Toxicity }\end{array}$ & $\begin{array}{c}\geq \text { Grade } 2 \\
\text { Esophagitis }\end{array}$ \\
\hline Belkacémi et al. 2008 [32] & Prospective & 146 & Trastuzumab & $76 \%$ & NA & $10 \%$ & $51 \%$ & $12 \%$ \\
\hline Halyard et al. 2009 [30] & Prospective & 982 & Trastuzumab & $0 \%$ & $100 \%$ & $2.1 \%$ & $6.2 \%$ & NA \\
\hline Caussa et al. 2011 [29] & Prospective & 106 & Trastuzumab & $83 \%$ & $92 \%$ & $5.7 \%$ & $15.1 \%$ & $3.8 \%$ \\
\hline Jacob et al. 2014 [28] & Prospective & 308 & Trastuzumab & $73.7 \%$ & $90.9 \%$ & $25.8 \%$ & $2.9 \%$ & $1.6 \%$ \\
\hline $\begin{array}{c}\text { Aboudaram et al. } 2021 \\
{[31]}\end{array}$ & Retrospective & 55 & $\begin{array}{l}\text { Trastuzumab- } \\
\text { Pertuzumab }\end{array}$ & NA & NA & $0 \%$ & $30.9 \%$ & $1.8 \%$ \\
\hline
\end{tabular}

IMC: internal mammary chain.

\subsection{Target the Cell Cycle: CDK-Inhibitor}

In 2016, the phase 3 study PALOMA-2 showed that the addition of a CDK inhibitor to standard endocrine therapy significantly improved outcomes in the first-line treatment of ER-positive, HER2- negative advanced BC [61,62]. The development of palbociclib for the treatment of hormone-receptor-positive advanced $\mathrm{BC}$ was based on the findings of preclinical studies that identified a dependence of hormone receptor-positive BC on CDK signaling and a synergistic effect from targeting the ER, cyclin-D-CDK4/6-Rb pathway [63]. Several pre-clinical studies have shown that the combination of RT and palbociclib could increase the anti-tumor effect in brain cancer cell lines [64-66]. However, the clinical effects of combining palbociclib and RT is least well-known. Several small retrospective studies have reported that the combination of RT and CDK inhibitor was generally well tolerated [67]. The series mainly reported the follow-up of patients irradiated on metastatic lesions. In 2017, Hans et al. [68] reported in a short letter very preliminary results of five patients treated with this combination and did not observe increased toxicity, particularly hematological toxicity. Conversely, in a recent case report, Kawamoto et al. observed severe acute radiation-induced enterocolitis after combined palbociclib and palliative RT [69]. Another more recent study retrospectively evaluated the toxicity and the outcomes of 16 women who received palliative RT in close temporal proximity to palbociclib administration [70]. The following sites were irradiated in decreasing order of frequency: bone, brain, and mediastinum. Most of the hematologic toxicities were grade 1, and no acute or late $>$ grade 2 skin, neurologic, or gastrointestinal toxicities were noted. Therefore, the consequences of a such combination remain unknown and most radiation oncologists prefer to suspend the CDK-I during radiotherapy.

Although the use of CDK4/ 6 inhibitors is currently limited to the metastatic setting, there are ongoing efforts to evaluate the efficacy of CDK4/6 inhibitors in the upfront setting for women with locally advanced or high-risk ER+ disease [71]. In contrast to 
the conventional use of CDK4/6 inhibitors in the metastatic setting, Pesh et al. recently studied the effects of CDKi and radiation (RT) in multiple preclinical BC models [72]. They demonstrated that short-term treatment of ER+ BC cell lines with the CDK4/6 inhibitors palbociclib, ribociclib, and abemaciclib led to alterations in many cellular pathways, including suppression of cell cycle signaling and changes in the DNA damage response. In ER+ BC cells that are sensitive to CDK4/6 inhibitor monotherapy, the combination of CDK4/6 inhibition and ionizing RT led to significant radiosensitization with each of the three clinically approved CDK4/6 inhibitors. Petroni et al. [73] recently reported that radiotherapy given before CDK4/ 6 inhibitors produces superior antineoplastic effects compared with other therapeutic schedules. In a study published in 2020, authors reported the outcomes of nine patients with de novo metastatic breast carcinoma, who were at least stable after 6 months of palbociclib, received LR irradiation and palbociclib [74]. Palbociclib had to be discontinued during RT in two patients because of grade 3 dermatitis and pain, and grade 2 esophagitis, respectively. However, in the first case, the patient had undergone bilateral mastectomy and axillary lymph node dissection for very advanced LR disease before RT. This case was the only case in which the CTV included the bilateral chest wall and all bilateral regional lymph node areas. Moreover, in both cases, the PTV was particularly large compared to other LR irradiation volumes. It is therefore difficult to conclude that the combination of palbociclib and RT was responsible for these toxicities.

Currently, two ongoing clinical trials are testing the combination of palbociclib and RT. The ongoing prospective phase 2 ASPIRE (NCT03691493, accessed on date 2021 December) trial is assessing RT combined with palbociclib and hormone therapy for bone metastases in BC patients whereas the PALATINE (NCT03870919, accessed on date 2021 December) prospective trial will assess local breast treatment, surgery and/or RT in advanced BC.

\subsection{Target the DNA Repair: PARP-Inhibitor}

Poly-(adenosine diphosphate-ribose)-polymerase (PARP) is a family of enzymes involved in DNA replication, transcription, repair, and cell death. In 2005, two studies showed that dysfunction of homologous recombination such as in BRCA1 and BRCA2 mutated BC cells triggered a high sensitization to PARP-inhibitor $[75,76]$. The targeted treatments have also many qualities required for radiosensitizing effects [77]. Associated with PARP-inhibitor, RT would induce DNA damages, such as double-strand break, which could not be repaired, in particular in BRCA mutated [78]. Nevertheless, several studies demonstrated that radiosensitization was independent of BC intrinsic subtype and did not appear to be related to the BRCA1 mutation status [79,80]. In 2015, Jagsi et al. reported the toxicity data of a phase I study which included 30 patients receiving locoregional radiotherapy for local recurrence of Triple-negative BC, and PARP-inhibitor (Veliparib). Initially, the combination was well tolerated with only one grade 4 radiation-induced dermatitis [81]. However, the grade 3 toxicity rate was $46.7 \%$ at year 3 [82]. More recently, Loap et al. reported the first results of RADIOPARP (NCT03109080, accessed on date 2021 December), a phase 1 trial that evaluated the combination of Olaparib and RT for 24 patients with triple-negative BC [83]. At a 1-year follow-up, no treatment-related grade $\geq 3$ toxicity was observed [84]. One patient (4.2\%) had persistent grade 2 adverse events (breast pain, fibrosis, and deformity). Moreover, a phase 2 trial evaluating olaparib with RT for inflammatory TNBC is currently recruiting (NCT03598257, accessed on date 2021 December) and other PARP-inhibitors are under evaluation in phase 1 trials: rucaparib (NCT03542175, accessed on date 2021 December) and Niraparib (NCT03945721, accessed on date 2021 December). Although these results are very encouraging, it seems preferable to wait for the results of these prospective studies before routinely administering PARP-inhibitors and RT concurrently.

The Table 3 summarizes the main results of preclinical and clinical studies that evaluated the safety of the concomitant combination of radiotherapy and targeted therapy. 
Table 3. Main preclinical and clinical published results of the combination of targeted treatments and radiation therapy.

\begin{tabular}{|c|c|c|c|c|}
\hline Targeted Treatments & Main Preclinical Results & Ref. & Main Clinical Results & Ref. \\
\hline \multicolumn{5}{|l|}{ Estrogen receptor } \\
\hline SERM (Tamoxifen) & $\begin{array}{l}\text { In in vivo model: high } \\
\text { frequency of RIPF in } \\
\text { concurrent administration of } \\
\text { tamoxifen and RT }\end{array}$ & {$[5]$} & $\begin{array}{l}\text { In retrospective and prospetive } \\
\text { studies: high frequency of RIPF } \\
\text { in concurrent administration of } \\
\text { tamoxifen and RT }\end{array}$ & {$[6-8]$} \\
\hline Aromatase Inhibitor & $\begin{array}{c}\text { In in vivo model: low } \\
\text { frequency of RIPF in } \\
\text { concurrent administration of } \\
\text { AI and RT }\end{array}$ & {$[5]$} & $\begin{array}{l}\text { In retrospective studies: low } \\
\text { frequency of any grade } 3 \text { toxicity } \\
\text { (incuding RIPF) }\end{array}$ & [13-15] \\
\hline
\end{tabular}

\section{HER2-inhibitor}

Tastuzumab, Pertuzumab (both humanized monoclonal antibodies, directed against the extracellular domain of the receptor)
In in vitro models: HER2

reduces breast cancer celles radiosensitivity

$[23,24]$

In retrospective and prospetive studies: low frequency of cardiac toxicity in concurrent administration of

HER2-inhibitor and locoregional

RT and low frequency of brain toxicity in concurrent administration of

HER2-inhibitor and brain RT

In retrospective studie: high frequency of brain radionecrosis in concurrent administration of

In in vitro models: T-DM1

T-DM1 (antibody-drug conjugate) was not a radiation-sensitizer

on HER2-positive breast cancer cells
[42]

T-DM1 and brain SBRT, low frequency of cardiac toxicity in concurrent administration of T-DM1 and locoregional RT

In retrospective studie: low

In in vitro and in vivo models: lapatinib increased the radiosensitivity of $\mathrm{BC}$ cells lines and $\mathrm{BC}$ xenografts frequency of brain radionecrosis

$[44,85]$ in concurrent administration of

lapatinib and brain RT epidermal growth factor

(EGFR, ErbB-1) and HER2 (ErbB-2))

\section{VEGFR inhibitor}

\begin{tabular}{cccc}
\hline Bevacizumab & $\begin{array}{c}\text { In in vitro and in vivo } \\
\text { models: VEGF inhibitor has } \\
\text { a radiosensitizing effect } \\
\text { when it is combined with RT }\end{array}$ & $\begin{array}{c}\text { In retrospective studies; low } \\
\text { frequency of any grade } 3 \text { toxicity } \\
\text { in concurrent administration of } \\
\text { bevacizumab and RT }\end{array}$ \\
\hline [mmunotherapy & In in vivo model: Increase \\
overall survival in & immonogenic murine model \\
of metastatic BC & {$[54]$} & N/A \\
\hline $\begin{array}{c}\text { Ipilimumab (anti-CTLA-4 } \\
\text { antibody) }\end{array}$ & $\begin{array}{c}\text { In in vivo model: Antitumor } \\
\text { effects of concurrent } \\
\text { administration of RT and } \\
\text { nivolumab in established } \\
\text { triple-negative breast tumors }\end{array}$ & {$[55]$} & $\begin{array}{c}\text { In prospective study: outcomes } \\
\text { improvements in concurrent } \\
\text { administration of pertuzumab } \\
\text { and RT for metastatic BC, no } \\
\text { data for toxicity }\end{array}$ \\
\hline PD-1/PD-L1 antibody)
\end{tabular}


Table 3. Cont.

\begin{tabular}{|c|c|c|c|c|}
\hline Targeted Treatments & Main Preclinical Results & Ref. & Main Clinical Results & Ref. \\
\hline \multicolumn{5}{|l|}{ CDK inhibitor } \\
\hline $\begin{array}{c}\text { Palbociclib, ribociclib, } \\
\text { abemaciclib (tyrosine kinase } \\
\text { inhibitor targeting CDK } 4 / 6 \\
\text { cyclin D) }\end{array}$ & $\begin{array}{l}\text { In in vitro and in vivo } \\
\text { models: Coucurrent } \\
\text { administration of CDK } 4 / 6 \\
\text { inhibition and RT led to } \\
\text { significant radiosensitization } \\
\text { in multiple BC models }\end{array}$ & {$[72,73]$} & $\begin{array}{l}\text { In retrospective studies: several } \\
\text { cases of grade } 3 \text { toxicity }\end{array}$ & {$[69,70,74]$} \\
\hline \multicolumn{5}{|l|}{ PARP-inhibitor } \\
\hline $\begin{array}{c}\text { Olaparib, velaparib, rucaparib } \\
* \text {, niraparib * }\end{array}$ & $\begin{array}{l}\text { In in vitro study: Concurrent } \\
\text { administration of PARPi and } \\
\text { RT induce more DNA } \\
\text { damages in particular in } \\
\text { BRCA mutated BC cell lines }\end{array}$ & {$[80]$} & $\begin{array}{l}\text { In retrospective and prospective } \\
\text { studies: high frequency of late } \\
\text { toxicity with velaparib, low } \\
\text { frequence of late toxicity with } \\
\text { olaparib }\end{array}$ & {$[82,84]$} \\
\hline
\end{tabular}

In this table, we reported the main preclinical and clinical published results of the combination of targeted treatments and radiation therapy. The targets are in bold. Abbreviations: SERM: Selective estrogen receptor modulators, RIPF: radiation-induced pulmonary fibrosis, RT: radiation therapy, AI: aromatase inhibitor, HER2-inhibitor: Human Epidermal growth factor Receptor 2-inhibitor, EGFR: Epidermal growth factor Receptor, T-DM1: Trastuzumab emtansine, SBRT: stereotactic body radiation therapy, VEGFR-inhibitor: Vascular endothelial growth factor receptor inhibitor, BC: breast cancer, PARP-inhibitor: Poly-(adenosine diphosphate-ribose)-polymerase inhibitor. *: studies currently ongoing.

\section{Discussion}

In the present study, we have performed a comprehensive synthesis of knowledge on the combination of radiotherapy and targeted therapies currently used for the treatment of localized or metastatic breast cancer (BC).

It is important to note that more and more prospective studies are underway to investigate these combinations. However, the number of randomized trials is very limited (Table 1), and it would certainly be useful to propose a multicenter, randomized trial for each molecule to answer the question of the toxicity of these combinations. This is particularly important because the comparison of trials is not always obvious. Indeed, there is considerable heterogeneity among the reported studies regarding the dose and fractionation of radiation, the dosage of drugs, and the sequence of treatments used. This can lead to contradictory results as we have seen for tamoxifen and the risk of pulmonary fibrosis.

The study of the combination of new treatments with radiotherapy is complex because of the many factors involved. Concerning RT, dose and fractionation may in themselves have an impact on the outcome of a combination. It is particularly right for immunotherapy. In a murine model of weakly immunogenic BC (TSA cell line), Dewan et al. showed that the best abscopal effect was obtained with a dose of 24 Gy in 3 fractions of 8 Gy (vs 1.20 Gy and $5.6 \mathrm{~Gy}$ ) and when the anti-CTLA-4 antibody was administered over the days following irradiation, without exceeding a 4-day interval, beyond which the benefit of this combined treatment was no longer observed [85].

\section{Conclusions}

In conclusion, a large number of molecules continue to emerge and, in this context, care should be taken. For molecules for which there is sufficient pre-clinical and clinical scientific evidence, the concomitant association of locoregional or metastatic radiotherapy with this molecule seems feasible. For the others, it is necessary to wait for the results of clinical trials before allowing this type of combination.

Author Contributions: Conceptualization: A.B. and Y.K.; methodology, A.B. and Y.K.; formal analysis: A.B.; investigation: A.B.; writing-original draft preparation: A.B.; writing—review, and editing all the authors; supervision: Y.K.; funding acquisition: Y.K. All authors have read and agreed to the published version of the manuscript. 
Funding: This research received no external funding.

Conflicts of Interest: The authors declare no conflict of interest.

$\begin{array}{ll}\text { Abbreviations } \\ \text { ADC } & \text { antibody-drug conjugate } \\ \text { BC } & \text { breast cancer } \\ \text { BM } & \text { brain metastases } \\ \text { CDK-I } & \text { CDK inhibitor } \\ \text { EGFR } & \text { epidermal growth factor } \\ \text { ER } & \text { estrogen receptor } \\ \text { GnRH } & \text { gonadotropin hormone analogues } \\ \text { ICI } & \text { immune checkpoint inhibitors } \\ \text { LHRH } & \text { luteinizing hormone-releasing hormone } \\ \text { LVEF } & \text { Left ventricular ejection fraction } \\ \text { PD } & \text { pharmacodynamic } \\ \text { PF } & \text { pulmonary fibrosis } \\ \text { PK } & \text { pharmacokinetic } \\ \text { RT } & \text { radiation therapy } \\ \text { SBRT } & \text { stereotactic body RT } \\ \text { SERD } & \text { selective estrogen receptor degradants } \\ \text { SERM } & \text { selective estrogen receptor modulators } \\ \text { T-DM1 } & \text { Trastuzumab emtansine } \\ \text { TKI } & \text { tyrosine kinase inhibitor } \\ \text { WBRT } & \text { whole-brain RT }\end{array}$

\section{References}

1. EBCTCG. Effect of Radiotherapy after Breast-Conserving Surgery on 10-Year Recurrence and 15-Year Breast Cancer Death: Meta-Analysis of Individual Patient Data for 10801 Women in 17 Randomised Trials. Lancet 2011, 378, 1707-1716. [CrossRef]

2. Patel, H.K.; Bihani, T. Selective Estrogen Receptor Modulators (SERMs) and Selective Estrogen Receptor Degraders (SERDs) in Cancer Treatment. Pharmacol. Ther. 2018, 186, 1-24. [CrossRef] [PubMed]

3. Anzic, M.; Marinko, T. Effect of Adjuvant Hormonal Therapy on the Development of Pulmonary Fibrosis after Postoperative Radiotherapy for Breast Cancer. J. Breast Cancer 2020, 23, 449-459. [CrossRef] [PubMed]

4. Butta, A.; MacLennan, K.; Flanders, K.C.; Sacks, N.P.; Smith, I.; McKinna, A.; Dowsett, M.; Wakefield, L.M.; Sporn, M.B.; Baum, M. Induction of Transforming Growth Factor Beta 1 in Human Breast Cancer in Vivo Following Tamoxifen Treatment. Cancer Res. 1992, 52, 4261-4264. [PubMed]

5. Yavas, G.; Yavas, C.; Acar, H.; Toy, H.; Yuce, D.; Ata, O. Comparison of the Effects of Aromatase Inhibitors and Tamoxifen on Radiation-Induced Lung Toxicity: Results of an Experimental Study. Support Care Cancer 2013, 21, 811-817. [CrossRef] [PubMed]

6. Bentzen, S.M.; Skoczylas, J.Z.; Overgaard, M.; Overgaard, J. Radiotherapy-Related Lung Fibrosis Enhanced by Tamoxifen. J. Natl. Cancer Inst. 1996, 88, 918-922. [CrossRef] [PubMed]

7. Varga, Z.; Cserháti, A.; Kelemen, G.; Boda, K.; Thurzó, L.; Kahán, Z. Role of Systemic Therapy in the Development of Lung Sequelae after Conformal Radiotherapy in Breast Cancer Patients. Int. J. Radiat. Oncol. Biol. Phys. 2011, 80, 1109-1116. [CrossRef]

8. Dörr, W.; Bertmann, S.; Herrmann, T. Radiation Induced Lung Reactions in Breast Cancer Therapy. Modulating Factors and Consequential Effects. Strahlenther. Onkol. 2005, 181, 567-573. [CrossRef]

9. $\quad$ Pierce, L.J.; Hutchins, L.F.; Green, S.R.; Lew, D.L.; Gralow, J.R.; Livingston, R.B.; Osborne, C.K.; Albain, K.S. Sequencing of Tamoxifen and Radiotherapy after Breast-Conserving Surgery in Early-Stage Breast Cancer. J. Clin. Oncol. 2005, $23,24-29$. [CrossRef] [PubMed]

10. Harris, E.E.R.; Christensen, V.J.; Hwang, W.-T.; Fox, K.; Solin, L.J. Impact of Concurrent versus Sequential Tamoxifen with Radiation Therapy in Early-Stage Breast Cancer Patients Undergoing Breast Conservation Treatment. J. Clin. Oncol. 2005, 23, 11-16. [CrossRef] [PubMed]

11. Munshi, A.; Gupta, D. Concurrent versus Sequential Radiotherapy and Tamoxifen in Breast Cancer-The CONSET Trial Is Launched. Acta Oncol. 2011, 50, 154-155. [CrossRef] [PubMed]

12. Arimidex, Tamoxifen, Alone or in Combination Trialists' Group; Buzdar, A.; Howell, A.; Cuzick, J.; Wale, C.; Distler, W.; HoctinBoes, G.; Houghton, J.; Locker, G.Y.; Nabholtz, J.M. Comprehensive Side-Effect Profile of Anastrozole and Tamoxifen as Adjuvant Treatment for Early-Stage Breast Cancer: Long-Term Safety Analysis of the ATAC Trial. Lancet Oncol. 2006, 7, 633-643. [CrossRef] [PubMed] 
13. Bollet, M.A.; Kirova, Y.M.; Antoni, G.; Pierga, J.-Y.; Sigal-Zafrani, B.; Laki, F.; Campana, F.; Dendale, R.; Salmon, R.; Cottu, P.; et al. Responses to Concurrent Radiotherapy and Hormone-Therapy and Outcome for Large Breast Cancers in Post-Menopausal Women. Radiother. Oncol. 2007, 85, 336-345. [CrossRef] [PubMed]

14. Azria, D.; Belkacemi, Y.; Romieu, G.; Gourgou, S.; Gutowski, M.; Zaman, K.; Moscardo, C.L.; Lemanski, C.; Coelho, M.; Rosenstein, B.; et al. Concurrent or Sequential Adjuvant Letrozole and Radiotherapy after Conservative Surgery for Early-Stage Breast Cancer (CO-HO-RT): A Phase 2 Randomised Trial. Lancet Oncol. 2010, 11, 258-265. [CrossRef]

15. Chargari, C.; Castro-Pena, P.; Toledano, I.; Bollet, M.A.; Savignoni, A.; Cottu, P.; Laki, F.; Campana, F.; De Cremoux, P.; Fourquet, A.; et al. Concurrent Use of Aromatase Inhibitors and Hypofractionated Radiation Therapy. World J. Radiol. $2012,4,318-323$. [CrossRef]

16. Loap, P.; Kirova, Y.; Takanen, S.; Créhange, G.; Fourquet, A. Breast radiation therapy during COVID-19 outbreak: Practical advice. Cancer Radiother. 2020, 24, 196-198. [CrossRef] [PubMed]

17. Rozeboom, B.; Dey, N.; De, P. ER+ Metastatic Breast Cancer: Past, Present, and a Prescription for an Apoptosis-Targeted Future. Am. J. Cancer Res. 2019, 9, 2821-2831.

18. Metcalfe, C.; Ingalla, E.; Blake, R.; Chang, J.; Daemen, A.; De Bruyn, T.; Giltnane, J.; Guan, J.; Hafner, M.; Hartman, S.; et al. Abstract P5-04-07: GDC-9545: A Novel ER Antagonist and Clinical Candidate That Combines Desirable Mechanistic and Pre-Clinical DMPK Attributes. Cancer Res. 2019, 79, P5-04-07. [CrossRef]

19. Bihani, T.; Patel, H.K.; Arlt, H.; Tao, N.; Jiang, H.; Brown, J.L.; Purandare, D.M.; Hattersley, G.; Garner, F. Elacestrant (RAD1901), a Selective Estrogen Receptor Degrader (SERD), Has Antitumor Activity in Multiple ER+ Breast Cancer Patient-Derived Xenograft Models. Clin. Cancer Res. 2017, 23, 4793-4804. [CrossRef]

20. Patel, H.K.; Tao, N.; Lee, K.-M.; Huerta, M.; Arlt, H.; Mullarkey, T.; Troy, S.; Arteaga, C.L.; Bihani, T. Elacestrant (RAD1901) Exhibits Anti-Tumor Activity in Multiple ER+ Breast Cancer Models Resistant to CDK4/6 Inhibitors. Breast Cancer Res. 2019, 21, 146. [CrossRef]

21. Gombos, A. Selective Oestrogen Receptor Degraders in Breast Cancer: A Review and Perspectives. Curr. Opin. Oncol. 2019, 31, 424-429. [CrossRef] [PubMed]

22. Kümler, I.; Tuxen, M.K.; Nielsen, D.L. A Systematic Review of Dual Targeting in HER2-Positive Breast Cancer. Cancer Treat. Rev. 2014, 40, 259-270. [CrossRef] [PubMed]

23. Pietras, R.J.; Poen, J.C.; Gallardo, D.; Wongvipat, P.N.; Lee, H.J.; Slamon, D.J. Monoclonal Antibody to HER-2/Neureceptor Modulates Repair of Radiation-Induced DNA Damage and Enhances Radiosensitivity of Human Breast Cancer Cells Overexpressing This Oncogene. Cancer Res. 1999, 59, 1347-1355.

24. Hou, J.; Zhou, Z.; Chen, X.; Zhao, R.; Yang, Z.; Wei, N.; Ni, Q.; Feng, Y.; Yu, X.; Ma, J.; et al. HER2 Reduces Breast Cancer Radiosensitivity by Activating Focal Adhesion Kinase in Vitro and in Vivo. Oncotarget 2016, 7, 45186-45198. [CrossRef] [PubMed]

25. Denduluri, N.; Somerfield, M.R.; Eisen, A.; Holloway, J.N.; Hurria, A.; King, T.A.; Lyman, G.H.; Partridge, A.H.; Telli, M.L.; Trudeau, M.E.; et al. Selection of Optimal Adjuvant Chemotherapy Regimens for Human Epidermal Growth Factor Receptor 2 (HER2)-Negative and Adjuvant Targeted Therapy for HER2-Positive Breast Cancers: An American Society of Clinical Oncology Guideline Adaptation of the Cancer Care Ontario Clinical Practice Guideline. J. Clin. Oncol. 2016, 34, 2416-2427. [CrossRef] [PubMed]

26. Lidbrink, E.; Chmielowska, E.; Otremba, B.; Bouhlel, A.; Lauer, S.; Liste Hermoso, M.; Nüesch, E.; Shing, M.; Misra, V. A Real-World Study of Cardiac Events in >3700 Patients with HER2-Positive Early Breast Cancer Treated with Trastuzumab: Final Analysis of the OHERA Study. Breast Cancer Res. Treat. 2019, 174, 187-196. [CrossRef]

27. Bergom, C.; Bradley, J.A.; Ng, A.K.; Samson, P.; Robinson, C.; Lopez-Mattei, J.; Mitchell, J.D. Past, Present, and Future of Radiation-Induced Cardiotoxicity: Refinements in Targeting, Surveillance, and Risk Stratification. JACC CardioOncol. 2021, 3 , 343-359. [CrossRef] [PubMed]

28. Jacob, J.; Belin, L.; Pierga, J.Y.; Gobillion, A.; Vincent-Salomon, A.; Dendale, R.; Beuzeboc, P.; Campana, F.; Fourquet, A.; Kirova, Y.M. Concurrent Administration of Trastuzumab with Locoregional Breast Radiotherapy: Long-Term Results of a Prospective Study. Breast Cancer Res. Treat. 2014, 148, 345-353. [CrossRef]

29. Caussa, L.; Kirova, Y.M.; Gault, N.; Pierga, J.-Y.; Savignoni, A.; Campana, F.; Dendale, R.; Fourquet, A.; Bollet, M.A. The Acute Skin and Heart Toxicity of a Concurrent Association of Trastuzumab and Locoregional Breast Radiotherapy Including Internal Mammary Chain: A Single-Institution Study. Eur. J. Cancer 2011, 47, 65-73. [CrossRef]

30. Halyard, M.Y.; Pisansky, T.M.; Dueck, A.C.; Suman, V.; Pierce, L.; Solin, L.; Marks, L.; Davidson, N.; Martino, S.; Kaufman, P.; et al. Radiotherapy and Adjuvant Trastuzumab in Operable Breast Cancer: Tolerability and Adverse Event Data from the NCCTG Phase III Trial N9831. J. Clin. Oncol. 2009, 27, 2638-2644. [CrossRef] [PubMed]

31. Aboudaram, A.; Loap, P.; Loirat, D.; Dhia, S.B.; Cao, K.; Fourquet, A.; Kirova, Y. Pertuzumab and Trastuzumab Combination with Concomitant Locoregional Radiotherapy for the Treatment of Breast Cancers with HER2 Receptor Overexpression. Cancers 2021, 13, 4790. [CrossRef]

32. Belkacémi, Y.; Gligorov, J.; Ozsahin, M.; Marsiglia, H.; De Lafontan, B.; Laharie-Mineur, H.; Aimard, L.; Antoine, E.-C.; Cutuli, B.; Namer, M.; et al. Concurrent Trastuzumab with Adjuvant Radiotherapy in HER2-Positive Breast Cancer Patients: Acute Toxicity Analyses from the French Multicentric Study. Ann. Oncol. 2008, 19, 1110-1116. [CrossRef] [PubMed]

33. Ben Dhia, S.; Loap, P.; Loirat, D.; Vincent-Salomon, A.; Cao, K.; Escalup, L.; Fourquet, A.; Kirova, Y. Concurrent radiation therapy and dual HER2 blockade in breast cancer: Assessment of toxicity. Cancer Radiother. 2021, 25, 424-431. [CrossRef] [PubMed] 
34. Ajgal, Z.; de Percin, S.; Diéras, V.; Pierga, J.Y.; Campana, F.; Fourquet, A.; Kirova, Y.M. Combination of Radiotherapy and Double Blockade HER2 with Pertuzumab and Trastuzumab for HER2-Positive Metastatic or Locally Recurrent Unresectable and/or Metastatic Breast Cancer: Assessment of Early Toxicity. Cancer Radiother. 2017, 21, 114-118. [CrossRef] [PubMed]

35. Garcia-Alvarez, A.; Papakonstantinou, A.; Oliveira, M. Brain Metastases in HER2-Positive Breast Cancer: Current and Novel Treatment Strategies. Cancers 2021, 13, 2927. [CrossRef]

36. Chargari, C.; Idrissi, H.R.; Pierga, J.-Y.; Bollet, M.A.; Diéras, V.; Campana, F.; Cottu, P.; Fourquet, A.; Kirova, Y.M. Preliminary Results of Whole Brain Radiotherapy with Concurrent Trastuzumab for Treatment of Brain Metastases in Breast Cancer Patients. Int. J. Radiat. Oncol. Biol. Phys. 2011, 81, 631-636. [CrossRef]

37. Krop, I.; Winer, E.P. Trastuzumab Emtansine: A Novel Antibody-Drug Conjugate for HER2-Positive Breast Cancer. Clin. Cancer Res. 2014, 20, 15-20. [CrossRef]

38. Stumpf, P.K.; Cittelly, D.M.; Robin, T.P.; Carlson, J.A.; Stuhr, K.A.; Contreras-Zarate, M.J.; Lai, S.; Ormond, D.R.; Rusthoven, C.G.; Gaspar, L.E.; et al. Combination of Trastuzumab Emtansine and Stereotactic Radiosurgery Results in High Rates of Clinically Significant Radionecrosis and Dysregulation of Aquaporin-4. Clin. Cancer Res. 2019, 25, 3946-3953. [CrossRef]

39. Geraud, A.; Xu, H.P.; Beuzeboc, P.; Kirova, Y.M. Preliminary Experience of the Concurrent Use of Radiosurgery and T-DM1 for Brain Metastases in HER2-Positive Metastatic Breast Cancer. J. Neurooncol. 2017, 131, 69-72. [CrossRef]

40. von Minckwitz, G.; Huang, C.-S.; Mano, M.S.; Loibl, S.; Mamounas, E.P.; Untch, M.; Wolmark, N.; Rastogi, P.; Schneeweiss, A.; Redondo, A.; et al. Trastuzumab Emtansine for Residual Invasive HER2-Positive Breast Cancer. N. Engl. J. Med. 2019, 380, 617-628. [CrossRef]

41. Denduluri, N.; Somerfield, M.R.; Chavez-MacGregor, M.; Comander, A.H.; Dayao, Z.; Eisen, A.; Freedman, R.A.; Gopalakrishnan, R.; Graff, S.L.; Hassett, M.J.; et al. Selection of Optimal Adjuvant Chemotherapy and Targeted Therapy for Early Breast Cancer: ASCO Guideline Update. J. Clin. Oncol. 2020, 39, 685-693. [CrossRef]

42. Mignot, F. In Vitro Effects of Trastuzumab Emtansine (T-DM1) and Concurrent Irradiation on HER2-Positive Breast Cancer Cells. Cancer/Radiothérapie 2021, 25, 126-134. [CrossRef]

43. Zolcsák, Z.; Loirat, D.; Fourquet, A.; Kirova, Y.M. Adjuvant Trastuzumab Emtansine (T-DM1) and Concurrent Radiotherapy for Residual Invasive HER2-Positive Breast Cancer: Single-Center Preliminary Results. Am. J. Clin. Oncol. 2020, 43, 895-901. [CrossRef] [PubMed]

44. Sambade, M.J.; Kimple, R.J.; Camp, J.T.; Peters, E.; Livasy, C.A.; Sartor, C.I.; Shields, J.M. Lapatinib in Combination with Radiation Diminishes Tumor Regrowth in HER2+ and Basal-Like/EGFR+ Breast Tumor Xenografts. Int. J. Radiat. Oncol. Biol. Phys. 2010, 77, 575-581. [CrossRef]

45. Christodoulou, C.; Kalogera-Fountzila, A.; Karavasilis, V.; Kouvatseas, G.; Papandreou, C.N.; Samantas, E.; Varaki, K.; Papadopoulos, G.; Bobos, M.; Rallis, G.; et al. Lapatinib with Whole Brain Radiotherapy in Patients with Brain Metastases from Breast and Non-Small Cell Lung Cancer: A Phase II Study of the Hellenic Cooperative Oncology Group (HeCOG). J. Neurooncol. 2017, 134, 443-451. [CrossRef]

46. Kim, J.M.; Miller, J.A.; Kotecha, R.; Chao, S.T.; Ahluwalia, M.S.; Peereboom, D.M.; Mohammadi, A.M.; Barnett, G.H.; Murphy, E.S.; Vogelbaum, M.A.; et al. Stereotactic Radiosurgery with Concurrent HER2-Directed Therapy Is Associated with Improved Objective Response for Breast Cancer Brain Metastasis. Neuro-Oncology 2019, 21, 659-668. [CrossRef] [PubMed]

47. Pierga, J.-Y.; Petit, T.; Delozier, T.; Ferrero, J.-M.; Campone, M.; Gligorov, J.; Lerebours, F.; Roché, H.; Bachelot, T.; Charafe-Jauffret, E.; et al. Neoadjuvant Bevacizumab, Trastuzumab, and Chemotherapy for Primary Inflammatory HER2-Positive Breast Cancer (BEVERLY-2): An Open-Label, Single-Arm Phase 2 Study. Lancet Oncol. 2012, 13, 375-384. [CrossRef]

48. Robert, N.J.; Diéras, V.; Glaspy, J.; Brufsky, A.M.; Bondarenko, I.; Lipatov, O.N.; Perez, E.A.; Yardley, D.A.; Chan, S.Y.T.; Zhou, X.; et al. RIBBON-1: Randomized, Double-Blind, Placebo-Controlled, Phase III Trial of Chemotherapy with or without Bevacizumab for First-Line Treatment of Human Epidermal Growth Factor Receptor 2-Negative, Locally Recurrent or Metastatic Breast Cancer. J. Clin. Oncol. 2011, 29, 1252-1260. [CrossRef]

49. Schueneman, A.J.; Himmelfarb, E.; Geng, L.; Tan, J.; Donnelly, E.; Mendel, D.; McMahon, G.; Hallahan, D.E. SU11248 Maintenance Therapy Prevents Tumor Regrowth after Fractionated Irradiation of Murine Tumor Models. Cancer Res. 2003, 63, $4009-4016$. [PubMed]

50. Huber, P.E.; Bischof, M.; Jenne, J.; Heiland, S.; Peschke, P.; Saffrich, R.; Gröne, H.-J.; Debus, J.; Lipson, K.E.; Abdollahi, A. Trimodal Cancer Treatment: Beneficial Effects of Combined Antiangiogenesis, Radiation, and Chemotherapy. Cancer Res. 2005, 65, 3643-3655. [CrossRef]

51. Goyal, S.; Rao, M.S.; Khan, A.; Huzzy, L.; Green, C.; Haffty, B.G. Evaluation of Acute Locoregional Toxicity in Patients with Breast Cancer Treated with Adjuvant Radiotherapy in Combination with Bevacizumab. Int. J. Radiat. Oncol. Biol. Phys. 2011, 79, 408-413. [CrossRef]

52. Pernin, V.; Belin, L.; Cottu, P.; Bontemps, P.; Lemanski, C.; De La Lande, B.; Baumann, P.; Missohou, F.; Levy, C.; Peignaux, K.; et al. Radiotherapy Associated with Concurrent Bevacizumab in Patients with Non-Metastatic Breast Cancer. Breast 2014, 23, 816-820. [CrossRef]

53. Clément-Zhao, A.; Tanguy, M.-L.; Cottu, P.; De La Lande, B.; Bontemps, P.; Lemanski, C.; Baumann, P.; Savignoni, A.; Levy, C.; Peignaux, K.; et al. Toxicity of Locoregional Radiotherapy in Combination with Bevacizumab in Patients with Non-Metastatic Breast Cancer (TOLERAB): Final Long-Term Evaluation. PLoS ONE 2019, 14, e0221816. [CrossRef] 
54. Demaria, S.; Kawashima, N.; Yang, A.M.; Devitt, M.L.; Babb, J.S.; Allison, J.P.; Formenti, S.C. Immune-Mediated Inhibition of Metastases after Treatment with Local Radiation and CTLA-4 Blockade in a Mouse Model of Breast Cancer. Clin. Cancer Res. 2005, 11, 728-734. [PubMed]

55. Verbrugge, I.; Hagekyriakou, J.; Sharp, L.L.; Galli, M.; West, A.; McLaughlin, N.M.; Duret, H.; Yagita, H.; Johnstone, R.W.; Smyth, M.J.; et al. Radiotherapy Increases the Permissiveness of Established Mammary Tumors to Rejection by Immunomodulatory Antibodies. Cancer Res. 2012, 72, 3163-3174. [CrossRef] [PubMed]

56. Deng, L.; Liang, H.; Burnette, B.; Beckett, M.; Darga, T.; Weichselbaum, R.R.; Fu, Y.-X. Irradiation and Anti-PD-L1 Treatment Synergistically Promote Antitumor Immunity in Mice. J. Clin. Investig. 2014, 124, 687-695. [CrossRef]

57. Ho, A.Y.; Barker, C.A.; Arnold, B.B.; Powell, S.N.; Hu, Z.I.; Gucalp, A.; Lebron-Zapata, L.; Wen, H.Y.; Kallman, C.; D’ Agnolo, A.; et al. A Phase 2 Clinical Trial assessing the efficacy and Safety of Pembrolizumab and Radiotherapy in Patients with Metastatic Triple-Negative Breast Cancer. Cancer 2020, 126, 850-860. [CrossRef]

58. Barroso-Sousa, R.; Krop, I.E.; Trippa, L.; Tan-Wasielewski, Z.; Li, T.; Osmani, W.; Andrews, C.; Dillon, D.; Richardson, E.T.; Pastorello, R.G.; et al. A Phase II Study of Pembrolizumab in Combination With Palliative Radiotherapy for Hormone ReceptorPositive Metastatic Breast Cancer. Clin. Breast Cancer 2020, 20, 238-245. [CrossRef]

59. Cao, K.; Abbassi, L.; Romano, E.; Kirova, Y. Radiation Therapy and Immunotherapy in Breast Cancer Treatment: Preliminary Data and Perspectives. Expert Rev. Anticancer Ther. 2021, 21, 501-510. [CrossRef] [PubMed]

60. Deutsch, E.; Chargari, C.; Galluzzi, L.; Kroemer, G. Optimising Efficacy and Reducing Toxicity of Anticancer Radioimmunotherapy. Lancet Oncol. 2019, 20, e452-e463. [CrossRef]

61. Finn, R.S.; Martin, M.; Rugo, H.S.; Jones, S.; Im, S.-A.; Gelmon, K.; Harbeck, N.; Lipatov, O.N.; Walshe, J.M.; Moulder, S.; et al. Palbociclib and Letrozole in Advanced Breast Cancer. N. Engl. J. Med. 2016, 375, 1925-1936. [CrossRef]

62. Iwata, H.; Im, S.-A.; Masuda, N.; Im, Y.-H.; Inoue, K.; Rai, Y.; Nakamura, R.; Kim, J.H.; Hoffman, J.T.; Zhang, K.; et al. PALOMA-3: Phase III Trial of Fulvestrant With or Without Palbociclib in Premenopausal and Postmenopausal Women With Hormone Receptor-Positive, Human Epidermal Growth Factor Receptor 2-Negative Metastatic Breast Cancer That Progressed on Prior Endocrine Therapy-Safety and Efficacy in Asian Patients. J. Glob. Oncol. 2017, 3, 289-303. [CrossRef]

63. Finn, R.S.; Dering, J.; Conklin, D.; Kalous, O.; Cohen, D.J.; Desai, A.J.; Ginther, C.; Atefi, M.; Chen, I.; Fowst, C.; et al. PD 0332991, a Selective Cyclin D Kinase 4/6 Inhibitor, Preferentially Inhibits Proliferation of Luminal Estrogen Receptor-Positive Human Breast Cancer Cell Lines in Vitro. Breast Cancer Res. 2009, 11, R77. [CrossRef]

64. Michaud, K.; Solomon, D.A.; Oermann, E.; Kim, J.-S.; Zhong, W.-Z.; Prados, M.D.; Ozawa, T.; James, C.D.; Waldman, T. Pharmacologic Inhibition of Cyclin-Dependent Kinases 4 and 6 Arrests the Growth of Glioblastoma Multiforme Intracranial Xenografts. Cancer Res. 2010, 70, 3228-3238. [CrossRef] [PubMed]

65. Whittaker, S.; Madani, D.; Joshi, S.; Chung, S.A.; Johns, T.; Day, B.; Khasraw, M.; McDonald, K.L. Combination of Palbociclib and Radiotherapy for Glioblastoma. Cell Death Discov. 2017, 3, 17033. [CrossRef] [PubMed]

66. Hashizume, R.; Zhang, A.; Mueller, S.; Prados, M.D.; Lulla, R.R.; Goldman, S.; Saratsis, A.M.; Mazar, A.P.; Stegh, A.H.; Cheng, S.-Y.; et al. Inhibition of DNA Damage Repair by the CDK4/6 Inhibitor Palbociclib Delays Irradiated Intracranial Atypical Teratoid Rhabdoid Tumor and Glioblastoma Xenograft Regrowth. Neuro-Oncology 2016, 18, 1519-1528. [CrossRef] [PubMed]

67. Bosacki, C.; Bouleftour, W.; Sotton, S.; Vallard, A.; Daguenet, E.; Ouaz, H.; Cojoracu, I.; Moslemi, D.; Molekzadehmoghani, M.; Magné, N. CDK 4/6 Inhibitors Combined with Radiotherapy: A Review of Literature. Clin. Transl. Radiat. Oncol. 2021, 26, 79-85. [CrossRef] [PubMed]

68. Hans, S.; Cottu, P.; Kirova, Y.M. Preliminary Results of the Association of Palbociclib and Radiotherapy in Metastatic Breast Cancer Patients. Radiother. Oncol. 2018, 126, 181. [CrossRef] [PubMed]

69. Kawamoto, T.; Shikama, N.; Sasai, K. Severe Acute Radiation-Induced Enterocolitis after Combined Palbociclib and Palliative Radiotherapy Treatment. Radiother. Oncol. 2018, 131, 240-241. [CrossRef] [PubMed]

70. Chowdhary, M.; Sen, N.; Chowdhary, A.; Usha, L.; Cobleigh, M.A.; Wang, D.; Patel, K.R.; Barry, P.N.; Rao, R.D. Safety and Efficacy of Palbociclib and Radiation Therapy in Patients With Metastatic Breast Cancer: Initial Results of a Novel Combination. Adv. Radiat. Oncol. 2019, 4, 453-457. [CrossRef] [PubMed]

71. Gil-Gil, M.; Alba, E.; Gavilá, J.; de la Haba-Rodríguez, J.; Ciruelos, E.; Tolosa, P.; Candini, D.; Llombart-Cussac, A. The Role of CDK4/6 Inhibitors in Early Breast Cancer. Breast 2021, 58, 160-169. [CrossRef]

72. Pesch, A.M.; Hirsh, N.H.; Chandler, B.C.; Michmerhuizen, A.R.; Ritter, C.L.; Androsiglio, M.P.; Wilder-Romans, K.; Liu, M.; Gersch, C.L.; Larios, J.M.; et al. Short-Term CDK4/6 Inhibition Radiosensitizes Estrogen Receptor-Positive Breast Cancers. Clin. Cancer Res. 2020, 26, 6568-6580. [CrossRef] [PubMed]

73. Petroni, G.; Buqué, A.; Yamazaki, T.; Bloy, N.; Liberto, M.D.; Chen-Kiang, S.; Formenti, S.C.; Galluzzi, L. Radiotherapy Delivered before CDK4/6 Inhibitors Mediates Superior Therapeutic Effects in ER+ Breast Cancer. Clin. Cancer Res. 2021, 27, 1855-1863. [CrossRef] [PubMed]

74. Beddok, A.; Xu, H.P.; Henry, A.A.; Porte, B.; Fourquet, A.; Cottu, P.; Kirova, Y. Concurrent Use of Palbociclib and Radiation Therapy: Single-Centre Experience and Review of the Literature. Br. J. Cancer 2020, 123, 905-908. [CrossRef] [PubMed]

75. Bryant, H.E.; Schultz, N.; Thomas, H.D.; Parker, K.M.; Flower, D.; Lopez, E.; Kyle, S.; Meuth, M.; Curtin, N.J.; Helleday, T. Specific Killing of BRCA2-Deficient Tumours with Inhibitors of Poly(ADP-Ribose) Polymerase. Nature 2005, 434, 913-917. [CrossRef] [PubMed] 
76. Farmer, H.; McCabe, N.; Lord, C.J.; Tutt, A.N.J.; Johnson, D.A.; Richardson, T.B.; Santarosa, M.; Dillon, K.J.; Hickson, I.; Knights, C.; et al. Targeting the DNA Repair Defect in BRCA Mutant Cells as a Therapeutic Strategy. Nature 2005, 434, 917-921. [CrossRef]

77. Lesueur, P.; Chevalier, F.; Austry, J.-B.; Waissi, W.; Burckel, H.; Noël, G.; Habrand, J.-L.; Saintigny, Y.; Joly, F. Poly-(ADP-Ribose)Polymerase Inhibitors as Radiosensitizers: A Systematic Review of Pre-Clinical and Clinical Human Studies. Oncotarget 2017, 8 , 69105-69124. [CrossRef] [PubMed]

78. Cerrato, A.; Morra, F.; Celetti, A. Use of Poly ADP-Ribose Polymerase [PARP] Inhibitors in Cancer Cells Bearing DDR Defects: The Rationale for Their Inclusion in the Clinic. J. Exp. Clin. Cancer Res. 2016, 35, 179. [CrossRef] [PubMed]

79. Feng, F.Y.; Speers, C.; Liu, M.; Jackson, W.C.; Moon, D.; Rinkinen, J.; Wilder-Romans, K.; Jagsi, R.; Pierce, L.J. Targeted Radiosensitization with PARP1 Inhibition: Optimization of Therapy and Identification of Biomarkers of Response in Breast Cancer. Breast Cancer Res. Treat. 2014, 147, 81-94. [CrossRef] [PubMed]

80. Michmerhuizen, A.R.; Pesch, A.M.; Moubadder, L.; Chandler, B.C.; Wilder-Romans, K.; Cameron, M.; Olsen, E.; Thomas, D.G.; Zhang, A.; Hirsh, N.; et al. PARP1 Inhibition Radiosensitizes Models of Inflammatory Breast Cancer to Ionizing Radiation. Mol. Cancer Ther. 2019, 18, 2063-2073. [CrossRef]

81. Jagsi, R.; Griffith, K.A.; Moran, J.M.; Ficaro, E.; Marsh, R.; Dess, R.T.; Chung, E.; Liss, A.L.; Hayman, J.A.; Mayo, C.S.; et al. A Randomized Comparison of Radiation Therapy Techniques in the Management of Node-Positive Breast Cancer: Primary Outcomes Analysis. Int. J. Radiat. Oncol. Biol. Phys. 2018, 101, 1149-1158. [CrossRef] [PubMed]

82. Jagsi, R.; Griffith, K.A.; Bellon, J.R.; Woodward, W.A.; Horton, J.K.; Ho, A.; Feng, F.Y.; Speers, C.; Overmoyer, B.; Sabel, M.; et al. Concurrent Veliparib With Chest Wall and Nodal Radiotherapy in Patients With Inflammatory or Locoregionally Recurrent Breast Cancer: The TBCRC 024 Phase I Multicenter Study. J. Clin. Oncol. 2018, 36, 1317-1322. [CrossRef] [PubMed]

83. Loap, P.; Loirat, D.; Berger, F.; Ricci, F.; Vincent-Salomon, A.; Ezzili, C.; Mosseri, V.; Fourquet, A.; Ezzalfani, M.; Kirova, Y. Combination of Olaparib and Radiation Therapy for Triple Negative Breast Cancer: Preliminary Results of the RADIOPARP Phase 1 Trial. Int. J. Radiat. Oncol. Biol. Phys. 2021, 109, 436-440. [CrossRef] [PubMed]

84. Loap, P.; Loirat, D.; Berger, F.; Cao, K.; Ricci, F.; Jochem, A.; Raizonville, L.; Mosseri, V.; Fourquet, A.; Kirova, Y. Combination of Olaparib with Radiotherapy for Triple-Negative Breast Cancers: One-Year Toxicity Report of the RADIOPARP Phase I Trial. Int. J. Cancer 2021, 149, 1828-1832. [CrossRef] [PubMed]

85. Dewan, M.Z.; Galloway, A.E.; Kawashima, N.; Dewyngaert, J.K.; Babb, J.S.; Formenti, S.C.; Demaria, S. Fractionated but Not Single-Dose Radiotherapy Induces an Immune-Mediated Abscopal Effect When Combined with Anti-CTLA-4 Antibody. Clin. Cancer Res. 2009, 15, 5379-5388. [CrossRef] [PubMed] 